\title{
Os últimos anos do Reino do Norte (da guerra siro-efraimita à queda de Samaria) na pesquisa recente
}

\author{
Orientadora: Profa. Maria de Lourdes Corrêa Lima
}

Pesquisador: Willian Gomes Mendonça

Fonte: $\mathrm{CNPq}$

\section{Introdução}

A pesquisa sobre os últimos anos do Reino do Norte adotou como fundamento o estudo dos textos bíblicos ao lado dos estudos da arqueologia tradicional e recente. A partir destas três visões, pretendeu-se compreender a perspectiva do autor bíblico ao narrar os últimos anos do Reino do Norte em continuidade e descontinuidade com o dado histórico.

\section{Objetivos}

Apresentar a visão bíblica dos últimos anos do Reino do Norte a partir da guerra siro-efraimita até à queda da Samaria. E confrontar os textos bíblicos com a arqueologia tradicional e recente, a fim de especificar a intenção teológica dos textos bíblicos. 